\title{
Estrogen receptor alpha dinucleotide repeat polymorphism in Japanese patients with autoimmune thyroid diseases Yoshiyuki Ban ${ }^{1}$, Matsuo Taniyama ${ }^{1}$, Teruaki Tozaki ${ }^{2,3}$, Motowo Tomita $^{2}$ and Yoshio Ban $^{1}$
}

\author{
Address: ${ }^{1}$ Third Department of Internal Medicine, Showa University School of Medicine, Tokyo, Japan., ${ }^{2}$ Department of Physiological \\ Chemistry, School of Pharmaceutical Sciences, Showa University, Tokyo, Japan. and ${ }^{3}$ Department of Molecular Genetics, Laboratory of Racing \\ Chemistry, Tochigi-ken, Japan. \\ E-mail: Yoshiyuki Ban - yshsban@ns2.cc.showa-u.ac.jp Matsuo Taniyama - taniyama@ns2.cc.showa-u.ac.jp Teruaki Tozaki - \\ ttozaki@nyc.odn.ne.jp Motowo Tomita - tomitam@pharm.showa-u.ac.jp Yoshio Ban - yshsban@ns2.cc.showa-u.ac.jp
}

Published: 23 November 2000

BMC Medical Genetics 2000, I:I
Received: 0I November 2000

Accepted: 23 November 2000

This article is available from: http://www.biomedcentral.com//47I-2350/I//

\begin{abstract}
Background: The autoimmune thyroid diseases (AITDs), comprising Graves' disease (GD) and Hashimoto's thyroiditis $(\mathrm{HT})$, appear to develop as a result of complex interactions between predisposing genes and environmental triggers. Susceptibility to AITDs is conferred by genes in the human leukocyte antigen (HLA) and genes unlinked to HLA, including the CTLA-4 gene. Recently, an association to some estrogen receptor (ER) $\alpha$ genotypes with breast cancer, hypertension, osteoporosis, generalized osteoarthritis, and some autoimmune diseases such as rheumatoid arthritis has been reported. We have analyzed a dinucleotide (TA)n repeat polymorphism lying upstream of the human ER $\alpha$ gene in patients with AITDs and in normal subjects.
\end{abstract}

Results: Seventeen different alleles were found in I 30 patients with GD, 93 patients with HT, and 190 control subjects. There was no significant difference in the distributions of $E R \alpha$ alleles between patients and controls.

Conclusions: The present results do not support an association between the ER $\alpha$ gene and AITD in the Japanese population.

\section{Background}

Autoimmune thyroid diseases (AITDs), including Graves' disease (GD) and Hashimoto's thyroiditis (HT), are the most common human autoimmune diseases and are responsible for significant morbidity in premenopausal women. AITDs are caused by immune responses to the thyroid gland. In GD, the autoimmune process results in production of thyroid-stimulating antibodies and leads to hyperthyroidism, whereas in HT, the end result is thyroid cell death and hypothyroidism $[1,2]$.

The pathogenesis of AITDs involves complex interactions between genetic and environmental factors [3,4]. The genetic relations between GD and HT and the famil- ial and sporadic forms of these diseases are unclear. This problem, until now, has been addressed by studying a variety of candidate genes, primarily via association studies. Because it has been assumed that immune dysregulation and/or thyroid antigen presentation are involved in AITD, the candidate genes that have been tested comprised genes involved in immunoregulatory pathways and genes encoding for the major thyroid autoantigens. These genes included the human leukocyte antigen (HLA) [5], immunoglobulin $\mathrm{H}$ heavy chain [6], $\mathrm{T}$ cell receptor [7], interleukin-1 receptor antagonist [8], interferon- $\gamma$ [9], thyroid stimulating hormone receptor $[10,11]$, thyroid peroxidase [12], and cytotoxic T lymphocyte antigen-4 (CTLA-4) genes [13]. With the excep- 
tion of the HLA and CTLA-4 loci, the candidate genes examined gave either negative or equivocal results. Recently, the existence of an estrogen receptor (ER) $\alpha$ gene polymorphism has made clear, and its association to some variant $\mathrm{ER} \alpha$ genotypes with breast cancer [14,15], hypertension [16], osteoporosis [17,18], generalized osteoarthritis [19], and some autoimmune diseases such as rheumatoid arthritis [20] has been reported.

The ER $\alpha$ gene on chromosome 6q24-q27 is organized into eight exons and seven introns extending over approximately 140 kilobases [21]. ER $\alpha$ belongs to the nuclear hormone receptor superfamily and modulates the transcription of target genes in response to estrogen, a potent immunomodulatory hormone [22]. Estrogens appear to play a central role in the immune response and immune-mediated diseases [22]. In view of the possible role of estrogens in the pathogenesis of AITDs, we have analyzed a dinucleotide (TA)n repeat polymorphism lying upstream of the human ER $\alpha$ gene in patients with AITDs and in normal subjects.

\section{Results}

Seventeen different alleles were found in 130 patients with GD, 93 patients with HT, and 190 controls subjects. The various alleles were designated as $E R \alpha^{*} 1$ through $\mathrm{ER}^{*} \alpha 17$ according to their sizes, which ranged from 164 to $198 \mathrm{bp}$. The distribution of ER $\alpha$ alleles in the three groups is shown in Table 1. Allele frequencies in our GD patients and our control subjects did not differ significantly $\left(X^{2}=15.49,16\right.$ degrees of freedom, $\left.\rho=0.49\right)$. Allele frequencies in our HT patients and our control subjects also did not differ significantly $\left(X^{2}=14.62,16\right.$ degrees of freedom, $\rho=0.55$ ).

Table I: Allele frequencies of the ER $\alpha$ gene polymorphism in patients with AITDs and in control subjects

\begin{tabular}{|c|c|c|c|}
\hline ER $\alpha$ polymorphism & $\begin{array}{c}\text { Graves' disease } \\
\mathrm{n}=130,(260 \text { alleles }),(\%)\end{array}$ & $\begin{array}{l}\text { Hashimoto's thyroiditis } \\
n=93,(186 \text { alleles), (\%) }\end{array}$ & $\begin{array}{c}\text { Controls } \\
n=190,(380 \text { alleles }),(\%)\end{array}$ \\
\hline allele $* 1$ & $20(7.7 \%)$ & $13(7.0 \%)$ & $24(6.3 \%)$ \\
\hline allele $* 2$ & 40 (I5.3\%) & $34(18.3 \%)$ & $88(23.2 \%)$ \\
\hline allele $* 3$ & $49(18.7 \%)$ & $25(13.4 \%)$ & $58(15.3 \%)$ \\
\hline allele $* 4$ & $32(12.3 \%)$ & $26(14.0 \%)$ & $39(10.3 \%)$ \\
\hline allele $* 5$ & $7(2.7 \%)$ & $2(1.1 \%)$ & $13(3.4 \%)$ \\
\hline allele $* 6$ & $10(3.8 \%)$ & $8(4.3 \%)$ & $12(3.2 \%)$ \\
\hline allele $* 7$ & $19(7.3 \%)$ & $12(6.5 \%)$ & $23(6.1 \%)$ \\
\hline allele $* 8$ & $10(3.8 \%)$ & $12(6.5 \%)$ & $16(4.2 \%)$ \\
\hline allele *9 & $15(5.8 \%)$ & $10(5.4 \%)$ & $23(6.1 \%)$ \\
\hline allele $* 10$ & II (4.2\%) & $10(5.4 \%)$ & $15(3.9 \%)$ \\
\hline allele *II & $17(6.5 \%)$ & $12(6.5 \%)$ & 37 (9.7\%) \\
\hline allele $* 12$ & $14(5.4 \%)$ & $12(6.5 \%)$ & $18(4.7 \%)$ \\
\hline allele $* 13$ & $10(3.8 \%)$ & $7(3.8 \%)$ & $10(2.6 \%)$ \\
\hline allele $* 14$ & 5 (1.9\%) & $2(1.1 \%)$ & $2(0.5 \%)$ \\
\hline allele *15 & $\mathrm{I}(0.4 \%)$ & $0(0 \%)$ & I (0.3\%) \\
\hline allele $* 16$ & $0(0 \%)$ & $0(0 \%)$ & I (0.3\%) \\
\hline allele *17 & I $(0.4 \%)$ & I $(0.5 \%)$ & $0(0 \%)$ \\
\hline
\end{tabular}

The number of subjects is shown with the corresponding percentage in parentheses.

\section{Discussion and Conclusions}

$\mathrm{ER} \alpha$ belongs to the nuclear hormone receptor superfamily and modulates the transcription of target genes in response to estrogen [22]. Recent studies have shown the presence of ERas on the cells involved in the immune response, namely thymocyte, macrophages and endothelial cells [22]. Particular attention has been focused on the dose-dependent influence of estrogen on the immune response, which appears to be related to the clinical symptoms of autoimmunity (i.e. the effects of pregnancy or oral contraceptive pills) [22]. The influence of estrogens on cytokine production by target cells, through interference with their transcriptional activity, has also been the focus of various studies [22]. The effect of estrogens on the expression of the protooncogenes and oncosuppressor genes involved in programmed cell death (apoptosis) might also be relevant to human autoimmunity, in particular the uncontrolled synovial lining cell hyperplasia associated with rheumatoid arthritis and the prolonged T-cell survival in systemic lupus erythematosus [22]. Thus, we investigated the relation between a dinucleotide (TA)n repeat polymorphism lying upstream of the human ER $\alpha$ gene and AITDs. Our data did not appear to indicate any association between the ER $\alpha$ gene and the AITDs analyzed. This result might indicate of a large diversity in the genetic background of AITDs, although this 
observation deserves further analysis in a larger group of AITD patients.

\section{Materials and Methods Subjects}

One hundred and thirty unrelated Japanese women with GD and 93 unrelated Japanese women with HT were included in this study. GD was diagnosed on the basis of clinical symptoms and biochemical confirmation of hyperthyroidism, including diffuse goiter, ophthalmopathy, elevated radioactive iodine uptake, and thyroid hormone levels. HT patients had documented clinical and biochemical hypothyroidism requiring thyroid hormone replacement therapy and showed autoantibodies against thyroid peroxidase with or without antibodies against thyroglobulin. One hundred and ninety unrelated Japanese women without clinical evidence or family history of any autoimmune diseases were selected as normal control subjects. The research protocol was approved by the ethics committee of our hospital, and informed consent was obtained from all patients and controls.

\section{Determination of microsatellite polymorphism by polymerase chain reaction}

Genomic DNA was isolated from whole blood with a Genomix kit (Talent, Trieste, Italy). Microsatellite marker loci were typed with fluorescence-based methods $[23,24]$. The polymerase chain reaction (PCR) was performed with oligonucleotide primers designed to amplify a polymorphic (TA)n repeat at 1174-base pair upstream of the human ER $\alpha$ gene [18]. PCR was performed in a total volume of $20 \mu \mathrm{l}$ of the following mixture: $100 \mathrm{ng}$ of human genomic DNA; $5 \mathrm{pmol}$ of each primer (Cy-5'GACGCATGATATACTTCACC-3' and 5'-GCAGAATCAAATATCCAGATG-3'); $200 \mu \mathrm{M}$ of each dNTPs; $2 \mu \mathrm{l}$ of $10 \times$ reaction buffer (Takara Shuzo Co., Kyoto, Japan); and 1 unit of Taq DNA polymerase (Takara Shuzo Co.). Thirty PCR cycles of 2 min at $94^{\circ} \mathrm{C}, 1 \mathrm{~min}$ at $58^{\circ} \mathrm{C}$, and 1 min at $74^{\circ} \mathrm{C}$ were performed. The amplified fragments were analysed by electrophoresis with an automatic DNA sequencer using $8 \%$ or $6 \%$ polyacrylamide gels containing 7 M Urea (Amersham Pharmacia Biotech, Buckingamshire, UK). The raw data were converted to dinucleotide repeat polymorphic band patterns with the use of a software program (Amersham Pharmacia Biotech,). The length of TA repeat in each amplified product was determined by comparison with a ladder of control DNAs.

\section{Statistical Analyses}

Comparisons between the various alleles in patients with AITDs and in controls were made with the $\mathrm{X}^{2}$-test, and $\rho$ $<0.05$ was considered significant. Fisher's exact test was used when necessary. The relative risk was calculated by Woolf's method [25].

\section{Acknowledgments}

This work was supported in part by the High-Technology Research Center Project from the Ministry of Education, Science, Sports and Culture of Japan.

\section{References}

I. Davies TF: The pathogenesis of Graves' disease. In Werner and Ingbar's the Thyroid: A Fundamental and Clinical Text. Edited by Braverman LE, Utiger RD. Philadelphia: Lippincott-Raven, 1996, 525-536

2. Weetman AP: Chronic autoimmune thyroiditis. In Werner and Ingbar's the Thyroid: A Fundamental and Clinical Text. Edited by Braverman LE, Utiger RD. Philadelphia: Lippincott-Raven, 1996, 738-748

3. Tomer Y, Barbesino G, Greenberg DA, Davies TF: The immunogenetics of autoimmune diabetes and autoimmune thyroid disease. Trends Endocrinol Metab 1997, 8:63-70

4. Tomer Y, Davies TF: Infection, thyroid disease and autoimmunity. Endocr Rev 1993, I 4:107-120

5. Farid NR, Bear JC: The human major histocompatibility complex and endocrine disease. Endocr Rev 1981, 2:50-86

6. Nakao Y, Matsumoto H, Miyazaki T, Nishitani H, Takatsuki K, Kasukawa R, Nakayama S, Izumi S, Fujita T, Tsuji K: IgG heavy chain allotypes $(\mathbf{G m})$ in autoimmune diseases. Clin Exp Immunol 1980, 42:20-26

7. Pickerill AP, Watson PF, Tandon N, Weetman AP: T cell receptor beta chain gene polymorphisms in Graves' disease. Acta Endocrinol (Copenh) 1993, I 28:499-502

8. Cuddihy RM, Bahn RS: Lack of an association between alleles of interleukin-I receptor antagonist genes and Graves' disease in a North American Caucasian population. J Clin Endocrinol Metab 1996, 81:4476-4478

9. Siegmund T, Usadel KH, Donner H, Braun J, Walfish PG, Badenhoop $\mathrm{K}$ : Interferon-g gene microsatellite polymorphisms in patients with Graves' disease. Thyroid 1998, 8:1013-1017

10. De Roux N, Shields DC, Misrahi M, Ratanachaiyavong S, McGregor AM, Milgrom E: Analysis of the thyrotropin receptor as a candidate gene in familial Graves' disease. J Clin Endocrinol Metab 1996, 8 I:3483-3486

II. Allahabadia A, Heward JM, Mijovic C, Carr-Smith J, Daykin J, Cockram C, Barnett AH, Sheppard MC, Franklyn JA, Gough SC: Lack of association between polymorphism of the thyrotropin receptor gene and Graves' disease in United Kingdom and Hong Kong Chinese patients: case control and family-based studies. Thyroid 1998, 8:777-780

12. Pirro MT, De Filippis V, Di Cerbo A, Scillitani A, Liuzzi A, Tassi V: Thyroperoxidase microsatellite polymorphism in thyroid disease. Thyroid 1995, 5:46I-464

13. Yanagawa T, Hidaka Y, Guimaraes V, Soliman M, DeGroot LJ: CTLA4 gene polymorphism associated with Graves' disease in a Caucasian population. J Clin Endocrinol Metab I995, 80:4 I-45

14. Hill SM, Fuqua SAW, Chamness GC, Greene GL, McGuire WL: Estrogen receptor expression in human breast cancer associated with an estrogen receptor gene restriction fragment length polymorphism. Cancer Res 1989, 49:|45-|48

15. Yaith L, Dupont WD, Cavener DR, Parl FF: Analysis of the Pvu II restriction fragment-length polymorphism and exon structure of the estrogen receptor gene in breast cancer and peripheral blood. Cancer Res 1992, 52:77-83

16. Lehrer S, Rabin J, Kalir T, Schachter BS: Estrogen receptor variant and hypertension in women. Hypertension 1993, $21: 439-441$

17. Kobayashi S, Inoue S, Hosoi T, Ouchi Y, Shraki M, Orimo H: Association of bone mineral density with polymorphism of the estrogen receptor gene. J Bone Miner Res 1996, I I:306-3 I I

18. Sano M, Inoue S, Hosoi T, Ouchi Y, Emi M, Shiraki M, Orimo H: Association of estrogen receptor dinucleotide repeat polymorphism with osteoporosis. Biochem Biophys Res Commun I995, 21 7:378-383

19. Ushiyama T, Ueyama H, Inoue K, Nishioka J, Ohkubo I, Hukuda S: Estrogen receptor gene polymorphism and generalized osteoarthritis. J Rheumatol 1998, 25:134-137

20. Ushiyama T, Mori K, Inoue K, Huang J, Nishioka J, Hukuda S: Association of oestrogen receptor gene polymorphisms with age at onset of rheumatoid arthritis. Ann Rheum Dis 1999, 58:7-10

21. Ponglikitmongkol M, Green S, Chambon P: Genomic organization of the human oestrogen receptor gene. EMBO J 1988, 7:33853388 
22. Cutolo M, Sulli A, Seriolo B, Accardo S, Masi AT: Estrogens, the immune response and autoimmunity. Clin Exp Rheumatol 1995, 13:217-226

23. Reed PW, Davies JL, Copeman JB, Bennett ST, Palmer SM, Pritchard LE, Gough SCL, Kawaguchi Y, Cordell HJ, Balfour KM, Jenkins SC, Powell EE, Vignal A, Todd JA: Chromosome-specific microsatellite sets for fluorescence-based, semi-automated genome mapping. Nat Genet 1994, 7:390-395

24. Pritchard LE, Kawaguchi Y, Reed PW, Copeman JB, Davies JL, Barnett $\mathrm{AH}$, Bain SC, Todd JA: Analysis of the CD3 region and type I diabetes: application of fluorescence-based technology to linkage disequilibrium mapping. Hum Mol Genet 1995, 4:197-202

25. Woolf $B$ : On estimating the relation between blood group and disease. Ann Hum Genet 1955, 19:251-253

\section{Pre-publication history}

The pre-publication history for this papercan be accessed here:

\section{http://www.biomedcentral.com/content/ backmatter/1471-2350-1-1-b1.pdf}

Publish with BioMedcentral and every scientist can read your work free of charge

"BioMedcentral will be the most significant development for disseminating the results of biomedical research in our lifetime."

Paul Nurse, Director-General, Imperial Cancer Research Fund

Publish with BMc and your research papers will be:

- available free of charge to the entire biomedical community

- peer reviewed and published immediately upon acceptance

- cited in PubMed and archived on PubMed Central

- yours - you keep the copyright

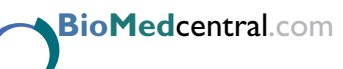

editorial@biomedcentral.com 